\title{
Avaliação do Efeito do Mel de Scaptotrigona Bipunctata (Lepeletier, 1836) Sobre Staphylococcus Aureus Meticilina-Resistente Através de Microscopia Eletrônica de Varredura.
}

Erick Kenji Nishio (I), Jhonatan Macedo Ribeiro (I), Renata Katsuko Takayama Kobayashi (I), Admilton Golçalves de Oliveira Junior (I), Edson Aparecido Proni (I), Gerson Nakazato (I)

(I) UEL - Universidade Estadual de Londrina (Rod Celso Garcia Cid Pr445 Km380 Cx Postal 10011 Londrina PR)

\section{Resumo}

O uso indiscriminado de antimicrobianos para o controle de infecções vem causando intensa pressão seletiva sobre os micro-organismos, selecionando organismos cada vez mais resistentes, levando ao surgimento de multirresistentes. Dentre esses podemos destacar Staphyolococcus aureus meticilina-resistente (MRSA) responsável por grande parte das infecções nosocomiais, considerado grande problema de saúde pública.

Pesquisadores vêm investindo em novos antimicrobianos, vários destes de origem natural, sendo o mel um dos produtos interessantes. Além de suas propriedades nutricionais e funcionais, diversos trabalhos comprovam a atividade antibacteriana de diferentes méis, porém poucos estudam as alterações causadas e o mecanismo de ação. Neste trabalho avaliamos a atividade antibacteriana do mel de abelha indígena sobre uma cepa de MRSA por meio de técnicas quantitativas e microscopia eletrônica de varredura (MEV). O mel de Scaptotrigona bipunctata foi coletado na região de Londrina-PR, diluído, esterilizado em filtro com poros de $0,22 \mu \mathrm{m}$, e testado contra a cepa de S. aureus MRSA N315. Testes iniciais foram realizados para determinar a concentração inibitória mínima (CIM) e a cinética do composto por meio de curva de crescimento e morte com contagem de colônias bacterianas. Para avaliar as alterações morfológicas

\footnotetext{
Referência:

Erick Kenji Nishio, Jhonatan Macedo Ribeiro, Renata Katsuko Takayama Kobayashi, Admilton Golçalves de Oliveira Junior, Edson Aparecido Proni, Gerson Nakazato. Avaliação do Efeito do Mel de Scaptotrigona Bipunctata (Lepeletier, 1836) Sobre Staphylococcus Aureus Meticilina-Resistente Através de Microscopia Eletrônica de Varredura.. In: Anais do $12^{\circ}$ Congresso Latinoamericano de Microbiologia e Higiene de Alimentos - MICROAL 2014 [= Blucher Food Science Proceedings, num.1, vol.1]. São Paulo: Editora Blucher, 2014. DOI 10.5151/foodsci-microal-280
} 
causadas pelo mel foram feitas imagens por MEV. O valor da CIM foi de $1,25 \%$, e quando incubado em diferentes tempos sobre esta concentração houve eliminação total da população bacteriana ao final de $24 \mathrm{~h}$. Pelas imagens de MEV podemos observar um grande número de células com septo de divisão, sugerindo inibição de enzimas autolíticas envolvidas no processo de degradação do peptidioglicano na região equatorial para a separação das células filhas. A partir dos resultados podemos comprovar a ação do mel frente à cepa de MRSA, sugerindo como uma possível alternativa para o controle microbiano. Além disso, estudos sobre alterações morfológicas são importantes para ajudarem a elucidar os possíveis mecanismos de ação.

Palavras-Chave: Mel, Abelhas indígenas, Microscopia eletrônica Agência de Fomento: CAPES, UEL. 